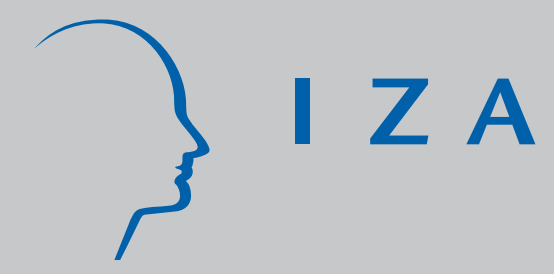

IZA DP No. 3510

Marriage, Partnership and Sexual Orientation: A Study of British University Academics and Administrators

Alison L. Booth J eff Frank

May 2008 


\title{
Marriage, Partnership and Sexual Orientation: A Study of British University Academics and Administrators
}

\author{
Alison L. Booth \\ RSSS, Australian National University \\ University of Essex, CEPR and IZA \\ Jeff Frank \\ Royal Holloway College, University of London
}

Discussion Paper No. 3510

May 2008

IZA

P.O. Box 7240

53072 Bonn

Germany

Phone: +49-228-3894-0

Fax: +49-228-3894-180

E-mail: iza@iza.org

Any opinions expressed here are those of the author(s) and not those of IZA. Research published in this series may include views on policy, but the institute itself takes no institutional policy positions.

The Institute for the Study of Labor (IZA) in Bonn is a local and virtual international research center and a place of communication between science, politics and business. IZA is an independent nonprofit organization supported by Deutsche Post World Net. The center is associated with the University of Bonn and offers a stimulating research environment through its international network, workshops and conferences, data service, project support, research visits and doctoral program. IZA engages in (i) original and internationally competitive research in all fields of labor economics, (ii) development of policy concepts, and (iii) dissemination of research results and concepts to the interested public.

IZA Discussion Papers often represent preliminary work and are circulated to encourage discussion. Citation of such a paper should account for its provisional character. A revised version may be available directly from the author. 


\begin{abstract}

\section{Marriage, Partnership and Sexual Orientation:} A Study of British University Academics and Administrators*

Using a unique data source on marital status, partnership and sexual orientation of academics and administrators at British universities, we estimate the impact of personal relationships upon earnings for men and women. While university data cover a relatively homogeneous group of workers, the two sides of the university are very different, with administrative jobs being more like the general job market in the economy. We find a large and significant married male premium, but only on the administrative side of the university. There is no female marriage premium, and no partnership return to gay men or to either heterosexual or homosexual women.
\end{abstract}

JEL Classification: J12, J16, J30, J45

Keywords: $\quad$ partnership, marriage, sexual orientation, academic labour markets

Corresponding author:

Jeff Frank

Department of Economics

Royal Holloway College

University of London

Egham Hill

Egham Surrey TW20 0EX

United Kingdom

E-mail: j.frank@rhul.ac.uk

\footnotetext{
* An earlier version of this paper was presented at the American Economic Association meetings in Boston, 2006. For their helpful suggestions, we thank the discussant, Ron Oaxaca, audience participants, the editors of this journal and two anonymous referees.
} 


\section{Introduction}

People enter into a variety of personal relationships. They can be unattached, in a partnership, or married. They can be heterosexual, bisexual or homosexual. They may have children. What are the wage implications of various forms of households? We investigate this using a unique data source on marital status, partnership and sexual orientation of academics and administrators at British universities.

Empirical studies show consistently that married men earn higher wages than women (both married and unmarried) and unmarried men. The premium may be a reward for higher productivity arising from a traditional household organisation where the male concentrates upon market production and the female upon household production (Becker, 1965). Alternatively, the measured differential may not be a direct return to marriage but may instead reflect a selection effect where more able males marry and less able males remain single. In both these cases, the higher wage may be in response to an individual's actual productivity, or it may reflect a form of statistical discrimination or signalling. A final possibility is that the married male premium reflects a taste for discrimination, and is not correlated with increased productivity. US studies, including Korenman and Neumark (1991), Akerlof (1998), and Lundberg and Rose (2002), and the UK study by Bardasi and Taylor (2005), seek to control for selection by using panel data and fixed effects estimation. These studies find that there remains a large married male wage differential after controlling for selection, which may make up half of the overall premium.

Since marriage is not generally available to lesbians and gay men, they are excluded from any direct earnings rewards due to marriage. It is therefore of interest whether or not 
unmarried partnership serves a similar role in leading to a wage premium for heterosexuals or for LGB (lesbian, gay and bisexual) individuals. A small literature has examined whether or not unmarried heterosexual cohabitation produces similar wage effects to marriage. The results are mixed. Stratton (2002) finds a positive return for males to cohabitation, but not after controlling for fixed effects. Loh (1996), in contrast, finds that the positive and significant return to cohabitation for males estimated using OLS actually increases using fixed-effects estimation. Mamum (2004) finds a positive and significant return to cohabitation for white and black men, but not for Hispanics, after controlling for selection.

LGB partnerships may differ in their economic impact compared to heterosexual partnerships. They may show greater equality in the allocation of market and home production tasks. There may be less of a selection effect if the mating process differs for LGB and heterosexual individuals. There is very little information in the literature about the effects of partnership among LGB people. Carpenter and Gates (2004) compare cohabiting and non-cohabiting gay men and find that their characteristics (such as education and income) differ significantly. Jepsen and Jepsen (2002) find that there is positive assortative mating (in both non-economic and labour market characteristics) for heterosexual marriages and partnerships, and same-sex cohabiting partnerships.

We use a unique dataset from British universities to examine the salary returns to different forms of relationships, taking account of sexuality and household organisation (such as childcare responsibilities). For heterosexual males, we find a significant return of $13 \%$ to marriage and an insignificant $6 \%$ return to unmarried partnership. This differs across the university: for administrators, the male marriage premium is over $21 \%$ while, for academics, it is statistically insignificant and of the same magnitude (about 7\%) as for 
females. LGB males and females have no return to partnership, on either the academic or administrative side of the university. Childcare responsibilities have no effect on earnings, having controlled for part-time working.

\section{The Data}

The UK Association of University Teachers (AUT) conducted an on-line survey of six representative British universities, between December 2000 and February 2001. The 'Fairness at Work' survey was organised by the AUT Equal Opportunities Committee to examine the treatment of sexual orientation, gender, and ethnicity in the academic labour market. With the permission of the Vice Chancellors, a letter was distributed to all staff inviting them to participate. A total of 813 responses were received, consisting of 51\% women and $49 \%$ men. Of these, only 706 were usable for this study because of missing information. Some 23 respondents did not provide information on sexual orientation, while 40 failed to provide information about salary and 42 failed to provide information about race. Academics comprised 54\% of the sample of 706 individuals and administrators $46 \%$.

The survey asked 38 questions covering issues including job characteristics (salary, type of university and location) and personal characteristics (age, experience, partnership status, childcare responsibilities, gender and sexuality). A full discussion of the data appears in Frank's (2006) study of wages and promotions. An extensive literature examines pay in universities (Ehrenberg, 2003). To our knowledge, ours is the first study to look at personal relationships in universities. 
Individuals were asked if they 'currently have a partner', without further definition in the survey, so this may include cohabiting and non-cohabiting relationships. There was a separate question about marriage. Marriage is prohibited among same-sex partners in the UK, although civil partnership (with equivalent rights to marriage) was introduced in 2005, after the AUT survey. The question used to elicit sexual orientation is: 'Which best indicates your sexual orientation at present? (Please indicate one) Heterosexual, Bisexual, Lesbian, Gay, Other'.

Table 1 gives the means of these and other variables used in our analysis. Age was obtained in bands in the survey. We converted these into the dummy variables shown in Table 1. University sector experience is in years. Human capital is measured by holding a $\mathrm{PhD}$, and also by undergraduate degree classification, where 'first class' is the top category, followed by 'upper second'. ${ }^{1}$ We include a dummy variable 'medicine subject area' to reflect the explicitly higher pay scales in this field. There is also a supplement paid to staff in London universities, so we include a dummy variable 'London'. Ethnicity is measured by 'white' and 'non-white'. Posts at all ranks can be held on a 'temporary' basis, for a fixed number of years, as well as with permanency ('tenure' or 'tenuretrack'). Posts at all ranks can also be held on a 'full time' or 'part time' basis.

\section{[Insert Table 1 near here]}

\footnotetext{
${ }^{1}$ Degrees in the UK are classified in accordance with grades received in exams over the 3-year period of the undergraduate degree, with a bigger weighting being given to the last year. A first-class degree is relatively rare in the overall population of university graduates. For example Booth (1993), using the 1986 British National Survey of 1980 Graduates, found that only $7 \%$ of employed male graduates and nearly $4 \%$ of employed female graduates held a first class degree, while $27 \%$ of male and $31 \%$ of female graduates held an upper-second class degree. In contrast, in our sample of university employees, $23 \%$ hold a firstclass degree, reflecting the higher academic ability of the sample.
} 
Column [1] gives means for the entire sample (both heterosexual and LGB), while Column [2] gives means for all heterosexuals, and Columns [3] and [4] give means for the heterosexuals disaggregated by whether they are employed as academics or administrators. The final column gives means for the LGB sub-sample. For heterosexual men (women), 61\% (46\%) are married and a further 25\% (36\%) are in an unmarried partnership. LGB individuals are $13 \%$ of the sample. ${ }^{2}$ The majority of gay men (58\%) and lesbians (60\%) are in a partnership, although these are smaller percentages than adding together marriages and unmarried partnerships for male and female heterosexuals. Individuals were asked if they 'have childcare responsibilities'. Affirmative answers represent a small proportion of each group (no more than 20\%), so it is reasonable to expect that individuals are referring to significant childcare responsibilities rather than just whether or not they have children. Childcare responsibilities are higher (17\% for males and $15 \%$ for females) for heterosexuals than for LGB (7\% for males and $6 \%$ for females).

We have done a number of calculations on the raw data, not reported in the Table. The lower figures for females in marriage and with childcare responsibilities probably arise from the fact that a much higher percentage are in the under 30 age range (26\% for heterosexual females and $13 \%$ for heterosexual males). In the raw data, heterosexual married males earn on average £35,754, well above the average for unmarried partnered heterosexual males $£ 28,212$, and that for single heterosexual males, £24,704. Among gay men, partnered individuals actually earn less on average, £28,616, than single individuals, £29,907. For heterosexual females, the figures are £26,547 (married),

\footnotetext{
${ }^{2}$ It is possible that the purpose of the survey - made clear in the cover letter - induced disproportionate participation by LGB individuals. Black et al. (2000) provide a comprehensive discussion of LGB representation in US data sources. In the US General Social Survey, 3.2\% of men and 2.6\% of women can be viewed as homosexual/bisexual, based on behaviour [Blandford (2003)].
} 
$£ 21,841$ (partnered), and £23,808 (single). Partnered lesbians earn an average of $£ 24,286$, less than single lesbians at $£ 27,092$. The raw data suggest a large marriage premium for heterosexual men, smaller premiums for married women and partnered heterosexual men, and a negative premium for partnered LGB.

Within the university, white collar jobs are relatively homogeneous and held by welleducated workers. However, there are important distinctions between academic and administrative jobs. Academic jobs have flexibility in scheduling hours of work between the university and home, which is particularly advantageous to women raising children. Administrative jobs are more like traditional jobs in the economy. ${ }^{3}$ There is also the belief that the academic side of the campus might be more comfortable with alternative lifestyles including LGB relationships and non-married heterosexual partnerships. The administrative side of the university might be more likely to reward traditional family structures, with a high male marriage premium. In Table 1, we present averages of the variables separately for heterosexual academics and administrators. The only clear differences are that the academics are more likely to be male and to have the highest undergraduate degree classification - "first class". They are also more likely to hold the $\mathrm{PhD}^{4}$ Using calculations not presented in the Table, the average salary for married male heterosexual academics is $£ 36,613$, while that for unmarried male heterosexual academics is $£ 29,191$. On the administrative side, the corresponding figures are $£ 34,109$ and $£ 24,597$, suggesting a larger marriage pay premium. There is evidence in the raw data of a wage penalty for gay men on the administrative side, with the average salary of heterosexual men being £29,608 and that of gay men being £25,901. For academics, the

\footnotetext{
${ }^{3}$ Note that in Britain it is not the case that all administrators were once academics. It is possible to become a university administrator via other avenues.

${ }^{4}$ The fact that a sizable proportion of our academic sample does not hold a PhD may be surprising to North American readers. It reflects the fact that, until around 25 years ago, it was possible to obtain an academic job with only a first-class undergraduate degree. Indeed, some of the most eminent of older UK academics
} 
average salary of heterosexual men is $£ 33,983$, while that of gay men is virtually the same at $£ 33,358$.

\section{Regression Results}

Although our data are cross-sectional, we initially set out a more general econometric model in order to highlight the various issues involved in estimating the wages effects of marriage and partnership for both heterosexuals and LGB. Suppose that the natural log of the annual salary $y_{i t}$ of individual $i$ in time $t$ is given as:

$$
y_{i t}=\mathbf{x}_{i t}^{\prime} \beta+\alpha_{m} m_{i t}+\alpha_{p} p_{i t}+v_{i}+e_{i t}
$$

where $\boldsymbol{x}$ is a vector of exogenous observable characteristics that influence $y, \beta$ is the vector of coefficients associated with $\boldsymbol{x}, \boldsymbol{m}$ denotes marital status and $p$ unmarried partnership status, and $v$ is an individual-specific unobservable term included to account for the possibility that there may be factors unobserved by the econometrician affecting the individual's market productivity and hence salary. Thus $v_{i}$ is interpreted as unobserved heterogeneity such as ability. Finally, $e_{i t}$ is the unobservable random error term assumed to be distributed independently of the $v_{i}$.

The coefficients $\alpha_{m}$ and $\alpha_{p}$ represent the ‘marriage' and 'partnership' premiums. The Becker (1965) model suggests that, in a traditional household, the male spouse (and perhaps, to a lesser extent, an unmarried male partner) will devote more time and effort to market production, while the female will devote more time and effort to household

production. As a result, $\alpha_{m}$ and $\alpha_{p}$ are typically thought to be positive for heterosexual 
males, and potentially negative for females. It is also generally believed that the allocation of tasks may be more equal in LGB partnerships, so that there is less reason for positive partnership premiums for gay men and negative ones for lesbian women. However, another explanation for positive marriage and partnership premiums is that there are increasing returns to household production - it is just as easy to cook for two as for one. In this case, the coefficients may be positive for LGB partnerships as well as for heterosexual marriages and partnerships. A further explanation for a positive marriage premium for heterosexual males is either a taste for discrimination, or a belief that married males are more stable than unmarried males [see Akerlof (1998)]. It is unlikely that gay men in partnerships would benefit from this effect.

Attempting to measure $\alpha_{m}$ and $\alpha_{p}$ by OLS leads to a potential bias due to selection effects. Although we cannot control for unobserved heterogeneity as our data are crosssectional, it is worth considering the potential direction of any bias. If unobserved heterogeneity (such as ability) $v_{i}$ is positively correlated with marriage and partnership, perhaps because more 'able' individuals have better social skills that encourage successful relationships, then even if $e_{i t}$ is $\operatorname{iidN}\left(0, \sigma^{2}{ }_{u}\right)$, estimating (1) by OLS leads to an over-estimate of the $\alpha$ values. If panel data were available, (1) could be differenced to remove any fixed effect of this sort. However, if (for example) marriage is endogenous and in particular depends upon $e_{i t}$ - perhaps because individuals with a positive earnings shock can afford the costs of marriage or have a greater incentive to have binding contracts over the disposition of assets in the event of a relationship breakdown - then even estimating the differenced equation leads to a biased estimate of $\alpha_{m}$. In any case, we have only cross-sectional data so we cannot difference (1) to remove any fixed effect. Insofar as, in both LGB partnerships and in heterosexual 
marriages, 'more is more' in choosing a partner, the selection effect is positive and the estimated $\alpha_{m}$ and $\alpha_{p}$ exceed the 'true' value. Both the household production effect and the selection effect suggest a positive heterosexual male marriage premium, while selection effects suggest a positive LGB male and female partnership premium. The household production effect and the selection effect are expected to operate in opposite directions for female heterosexual marriage. The selection effect for heterosexual unmarried partnerships proves to be complicated, as shown in Booth and Frank (2006), and can go in either direction.

Table 2 reports ordinary least squares (OLS) estimates of the log annual salary with respect to a number of individual and job characteristics. Employer-specific dummy variables control for employer fixed effects (unreported to preserve university anonymity).

\section{[Insert Table 2 near here]}

Column (1) reports estimates from the sample of all LGB individuals, with t-statistics in parentheses. We find small and insignificant negative partnership coefficients for both males and females. This is consistent with the idea that LGB individuals share market and household production more equally than in heterosexual marriages, and that they do not gain in partnerships from a positive taste for discrimination from employers. It is perhaps surprising that increasing returns to scale, and a positive selection effect, do not show up in a significant positive coefficient for either LGB men or women.

To provide a direct comparison between heterosexuals and homosexuals, we estimate in column (2) the full sample of heterosexuals, but combine both married and unmarried heterosexual partners into one variable. There is a statistically significant $10 \%$ gain to 
(combined married and unmarried) partnership for male heterosexuals, with a negative and insignificant effect for female heterosexuals. On the assumption that LGB and heterosexual men form partnerships on the basis of positive assortative matching, as in Jepsen and Jepsen (2002), the selection effect should be similar for the two groups. The difference in outcomes (with a positive heterosexual male partnership coefficient) therefore is likely to reflect household allocation of tasks and a taste for discrimination by employers.

Column (3) reports estimates from the sample of all heterosexuals, but distinguishing between marriage and unmarried partnerships. There is a statistically significant $13 \%$ marriage premium for men and none for women; there is an insignificant gender premium; and there are insignificant coefficients on childcare responsibilities for men and women. There is a positive but insignificant unmarried partnership premium for men, and a negative but insignificant one for women. We considered additional unreported estimations. Estimating only over the male heterosexual sample (284 individuals), we found a marriage effect of 0.1221 (t-statistic 1.96); over the female heterosexual sample (329 individuals), we find a marriage effect of 0.0166 (0.38). Among the unmarried partners in the survey, there may be both cohabiting and noncohabiting couples. While there is no direct question on cohabitation, the survey does ask whether 'you and your partner currently have any shared financial commitments (e.g. rent, mortgage, childcare, etc.)'. Among unmarried partners, this can be taken to represent a greater degree of commitment, and possibly a proxy measure for cohabitation. $^{5}$ Introducing this into the male heterosexual regression, but not reported in Table 2, we find the wage premiums: 0.1282 (t-stat 2.27) for marriage; 0.0745 (1.14) for

\footnotetext{
${ }^{5}$ Among married males, 94\% report shared financial commitments; among married females, 97\% report shared financial commitments. In contrast, 64\% (61\%) of unmarried male (female) heterosexuals with
} 
partnership with shared financial commitments; and 0.0229 (0.31) for other partnerships. This suggests that a higher degree of commitment in a relationship is reflected in a higher wage premium. None of the relationship coefficients are significant for heterosexual women.

Academic and administrative jobs are very different. For this reason we estimate separate regressions for heterosexuals holding administrative and those holding academic jobs, reported in Columns (4) and (5). ${ }^{6} \quad$ The main result is that the male marriage premium coefficient is much higher (and statistically significant) among administrators (21.21\%, t-statistic 2.19) than among academics (7.71\%, t-statistic 1.21). As a further test of whether or not the male marriage premium differs significantly across the academic and administrative sides of the university, we ran a regression (not reported in the Table) with marriage as the only relationship variable but allowing different coefficient values for academics and administrators on all variables. We found a married male premium of coefficient of 0.1821 (t-statistic 3.06) over all jobs, but with a negative additive impact for academics of -0.1498 (t-statistic 1.94, significant at 5.2\%).

\section{Interpretation and Conclusion}

University data have the advantage of presenting a relatively homogeneous group of well-educated workers, in what is typically perceived to be an enlightened sector in terms of attitudes to less traditional relationships. The homogeneity of the sample means that many of the causes of the gender pay gap - such as job segregation - tend not to hold.

\footnotetext{
partners report shared financial commitments. The figures for LGB men and women are 55\% and $62 \%$.

${ }^{6}$ We also experimented with running a pooled regression with academic status interacted with LGB and
} 
However, the academic and the administrative sides of the university are very different in terms of job flexibility and in attitudes. This study is the first, to our knowledge, that looks at the impact of traditional marriage and non-traditional relationships on wages in the university sector.

Our main results can be summarised as follows:

- We find small and insignificant negative partnership coefficients for both male and female LGB, as compared with non-partnered LGB. This is consistent with the idea that LGB individuals share market and household production more equally than in heterosexual marriages, and that they do not gain in partnerships from a positive taste for discrimination from employers.

- For heterosexuals, for whom we are able to distinguish between marriage and unmarried partnerships, there is a statistically significant $13 \%$ marriage premium for men and none for women. There is a positive but insignificant unmarried partnership premium for men, and a negative but insignificant one for women.

- To compare directly heterosexuals and homosexuals, we also combined both married and unmarried heterosexual partners into one variable, and find a significant $10 \%$ gain to (combined married and unmarried) partnership for male heterosexuals, with a negative and insignificant effect for female heterosexuals.

- Because academic and administrative jobs are very different, we also estimate separate regressions for heterosexuals holding either administrative or academic jobs, and find that the male marriage premium coefficient is much higher among administrators than among academics.

- The gender coefficient is insignificant once we allow for gender-specific marriage and partnership effects. The persistence of gender pay gaps in the economy does 
not mean that all women do worse than all men - our results suggest that the beneficiaries of the gender pay gap are married men, not single men.

- Childcare responsibilities seem to have no effect for our sample. It is likely that the relative flexibility of even full-time university jobs - in terms of choice of hours worked and location - limits negative pay impacts in both academic and administrative jobs.

Our new results have potential implications for understanding the male marriage premium and support research that shows there may only be a limited explanatory role for selection (see Antonovics and Town (2004), Chun and Lee (2001) and Ginther and Zavodny (1998)). The alternative explanation in the literature emphasises traditional household arrangements or a taste by the employer for rewarding traditional marriage. It is possible that this is more likely to hold on the administrative side of the university, and this may explain the high magnitude of the male marriage premium for administrators relative to academics.

Since LGB partners are generally prevented from marriage, and thereby gaining from any associated marriage wage premium, it is of interest to ask whether a similar premium holds for partnerships. Unmarried heterosexual and LGB partnerships may not follow a traditional household allocation of tasks to the same extent as with marriage. However, partnerships might gain in the same way as marriage from economies of scale in home production, allowing both partners to devote more effort to market production. Unmarried partners might also gain from a selection effect in terms of ability and an enlightened employer might see LGB partnerships in particular as showing a degree of stability not evidenced by single males or unmarried heterosexual partners. It is therefore important that our results show no return to partnership for LGB males or females. It 
may be that formal civil partnerships, introduced in some US states and in the UK, will have a more positive effect than the informal partnerships in our data. This represents an interesting avenue for future research. 
Table 1. Means and Percentages of Variables

\begin{tabular}{|c|c|c|c|c|c|}
\hline $\begin{array}{l}\text { Independent } \\
\text { variables }\end{array}$ & $\begin{array}{l}\quad[1] \\
\text { Mean - whole } \\
\text { sample }\end{array}$ & \begin{tabular}{l}
\multicolumn{1}{c}{$\quad[2]$} \\
Mean - whole \\
sample \\
(heterosexuals)
\end{tabular} & $\begin{array}{l}\quad \text { [3] } \\
\text { Mean - } \\
\text { academics } \\
\text { (heterosexuals) }\end{array}$ & \begin{tabular}{l}
\multicolumn{1}{c}{$[4]$} \\
Mean - \\
administrators \\
(heterosexuals)
\end{tabular} & $\begin{array}{l}\text { [5] } \\
\text { Mean - } \\
\text { LGB } \\
\text { sample }\end{array}$ \\
\hline Salary & $£ 27,968$ & $£ 28,031$ & $£ 30.234$ & $£ 25,340$ & $£ 27,554$ \\
\hline Experience (yrs.) & 10.07 & 10.21 & 10.88 & 9.38 & 9.11 \\
\hline \multicolumn{6}{|c|}{ Percentage of the Sample with the Characteristic: } \\
\hline Age under 30 & 0.19 & 0.20 & 0.18 & 0.22 & 0.15 \\
\hline Age $30-39$ & 0.36 & 0.35 & 0.38 & 0.31 & 0.45 \\
\hline Age $40-49$ & 0.26 & 0.25 & 0.23 & 0.27 & 0.31 \\
\hline Age $50-59$ & 0.17 & 0.18 & 0.18 & 0.18 & 0.08 \\
\hline Age 60 and over & 0.02 & 0.02 & 0.03 & 0.01 & 0.01 \\
\hline London & 0.21 & 0.20 & 0.21 & 0.18 & 0.23 \\
\hline White & 0.95 & 0.95 & 0.96 & 0.95 & 0.91 \\
\hline First class degree & 0.23 & 0.22 & 0.32 & 0.10 & 0.23 \\
\hline $\begin{array}{l}\text { Upper second class } \\
\text { degree }\end{array}$ & 0.37 & 0.36 & 0.37 & 0.36 & 0.39 \\
\hline $\mathrm{PhD}$ & 0.46 & 0.47 & 0.67 & 0.23 & 0.34 \\
\hline Academic staff & 0.54 & 0.54 & 1.00 & 0.00 & 0.46 \\
\hline $\begin{array}{l}\text { Medicine subject } \\
\text { area }\end{array}$ & 0.22 & 0.22 & 0.27 & 0.15 & 0.23 \\
\hline Temporary post & 0.44 & 0.44 & 0.45 & 0.43 & 0.43 \\
\hline Full time post & 0.89 & 0.88 & 0.90 & 0.85 & 0.89 \\
\hline Male & 0.47 & 0.46 & 0.51 & 0.39 & 0.53 \\
\hline \multicolumn{6}{|c|}{ Percentage of the Male/Female Sub-sample with the Characteristic: } \\
\hline $\begin{array}{l}\text { Childcare } \\
\text { responsibilities - } \\
\text { male }\end{array}$ & 0.16 & 0.17 & 0.19 & 0.14 & 0.07 \\
\hline $\begin{array}{l}\text { Childcare } \\
\text { responsibilities - } \\
\text { female }\end{array}$ & 0.15 & 0.15 & 0.14 & 0.17 & 0.06 \\
\hline Married - male & 0.51 & 0.61 & 0.65 & 0.54 & 0.00 \\
\hline Married - female & 0.41 & 0.46 & 0.45 & 0.47 & 0.00 \\
\hline $\begin{array}{l}\text { Non-married } \\
\text { partner - male }\end{array}$ & 0.30 & 0.25 & 0.23 & 0.28 & 0.58 \\
\hline $\begin{array}{l}\text { Non-married } \\
\text { partner - female }\end{array}$ & 0.40 & 0.36 & 0.37 & 0.35 & 0.60 \\
\hline Sample size & 706 & 613 & 337 & 276 & 93 \\
\hline
\end{tabular}


Table 2. OLS Log Salary Regressions

\begin{tabular}{|c|c|c|c|c|c|}
\hline Independent variables & $\begin{array}{c}{[1]} \\
\text { LGB }\end{array}$ & $\begin{array}{c}{[2]} \\
\text { All heterosexuals }\end{array}$ & $\begin{array}{c}{[3]} \\
\text { All heterosexuals }\end{array}$ & $\begin{array}{c}{[4]} \\
\text { Administrator } \\
\text { heterosexuals }\end{array}$ & $\begin{array}{c}{[5]} \\
\text { Academic } \\
\text { heterosexuals }\end{array}$ \\
\hline Constant & $\begin{array}{l}9.4812 \\
(38.60)\end{array}$ & $\begin{array}{l}9.4809 \\
(102.55)\end{array}$ & $\begin{array}{l}9.4790 \\
(102.50)\end{array}$ & $\begin{array}{l}9.4267 \\
(62.52)\end{array}$ & $\begin{array}{l}9.6736 \\
(85.44)\end{array}$ \\
\hline \multicolumn{6}{|l|}{ Gender \& Family } \\
\hline Male & $\begin{array}{l}0.0212 \\
(0.20)\end{array}$ & $\begin{array}{l}-0.0148 \\
(0.25)\end{array}$ & $\begin{array}{l}-0.0128 \\
(0.21)\end{array}$ & $\begin{array}{l}-0.0849 \\
(0.85)\end{array}$ & $\begin{array}{l}0.0479 \\
(0.67)\end{array}$ \\
\hline Childcare responsibilities & 0.0397 & 0.0107 & -0.0028 & 0.0158 & -0.0370 \\
\hline - male & $(0.31)$ & $(0.28)$ & $(0.07)$ & $(0.20)$ & $(0.87)$ \\
\hline Childcare responsibilities & 0.0848 & 0.0173 & 0.0154 & 0.0318 & -0.0164 \\
\hline - female & $(0.62)$ & $(0.44)$ & $(0.38)$ & $(0.46)$ & $(0.34)$ \\
\hline Married - male & & & $\begin{array}{l}0.1320 \\
(2.39)\end{array}$ & $\begin{array}{l}0.2121 \\
(2.19)\end{array}$ & $\begin{array}{l}0.0771 \\
(1.21)\end{array}$ \\
\hline Married - female & & & $\begin{array}{l}-0.0051 \\
(0.11)\end{array}$ & $\begin{array}{l}-0.0555 \\
(0.71)\end{array}$ & $\begin{array}{l}0.0642 \\
(1.11)\end{array}$ \\
\hline Partnered - male & $\begin{array}{l}-0.0114 \\
(0.13)\end{array}$ & $\begin{array}{l}0.1048 \\
(2.01)\end{array}$ & $\begin{array}{l}0.0652 \\
(1.11)\end{array}$ & $\begin{array}{l}0.0584 \\
(0.59)\end{array}$ & $\begin{array}{l}0.0526 \\
(0.76)\end{array}$ \\
\hline Partnered - female & $\begin{array}{l}-0.0507 \\
(0.53)\end{array}$ & $\begin{array}{l}-0.0126 \\
(0.29)\end{array}$ & $\begin{array}{l}-0.0866 \\
(1.15)\end{array}$ & $\begin{array}{l}-0.0732 \\
(0.58)\end{array}$ & $\begin{array}{l}-0.0793 \\
(-0.88)\end{array}$ \\
\hline Other Attributes & & & & & \\
\hline Age 30-39 & $\begin{array}{l}0.1816 \\
(1.86)\end{array}$ & $\begin{array}{l}0.1405 \\
(3.70)\end{array}$ & $\begin{array}{l}0.1362 \\
(3.56)\end{array}$ & $\begin{array}{l}0.1455 \\
(2.26)\end{array}$ & $\begin{array}{l}0.1147 \\
(2.57)\end{array}$ \\
\hline Age $40-49$ & $\begin{array}{l}0.4007 \\
(3.26)\end{array}$ & $\begin{array}{l}0.2121 \\
(4.39)\end{array}$ & $\begin{array}{l}0.2010 \\
(4.09)\end{array}$ & $\begin{array}{l}0.2003 \\
(2.51)\end{array}$ & $\begin{array}{l}0.2083 \\
(3.42)\end{array}$ \\
\hline Age 50-59 & $\begin{array}{l}0.5455 \\
(2.91)\end{array}$ & $\begin{array}{l}0.3043 \\
(5.52)\end{array}$ & $\begin{array}{l}0.2923 \\
(5.20)\end{array}$ & $\begin{array}{l}0.2322 \\
(2.65)\end{array}$ & $\begin{array}{l}0.3293 \\
(4.56)\end{array}$ \\
\hline Age 60 and over & $\begin{array}{l}0.1569 \\
(0.46)\end{array}$ & $\begin{array}{l}0.3762 \\
(3.62)\end{array}$ & $\begin{array}{l}0.3621 \\
(3.46)\end{array}$ & $\begin{array}{l}0.3527 \\
(1.60)\end{array}$ & $\begin{array}{l}0.3768 \\
(3.24)\end{array}$ \\
\hline Experience & $\begin{array}{l}0.0224 \\
(1.42)\end{array}$ & $\begin{array}{l}0.0217 \\
(4.15)\end{array}$ & $\begin{array}{l}0.0219 \\
(4.18)\end{array}$ & $\begin{array}{l}0.0277 \\
(3.11)\end{array}$ & $\begin{array}{l}0.0099 \\
(1.56)\end{array}$ \\
\hline Experience sq & $\begin{array}{l}-0.0007 \\
(1.16)\end{array}$ & $\begin{array}{l}-0.0004 \\
(2.70)\end{array}$ & $\begin{array}{l}-0.0004 \\
(2.78)\end{array}$ & $\begin{array}{l}-0.0005 \\
(1.97)\end{array}$ & $\begin{array}{l}-0.0001 \\
(1.07)\end{array}$ \\
\hline London & $\begin{array}{l}0.2377 \\
(0.86)\end{array}$ & $\begin{array}{l}0.1055 \\
(1.25)\end{array}$ & $\begin{array}{l}0.1006 \\
(1.20)\end{array}$ & $\begin{array}{l}0.2081 \\
(1.35)\end{array}$ & $\begin{array}{l}0.0084 \\
(0.09)\end{array}$ \\
\hline White & $\begin{array}{l}0.0031 \\
(0.03)\end{array}$ & $\begin{array}{l}-0.0672 \\
(1.11)\end{array}$ & $\begin{array}{l}-0.0591 \\
(0.97)\end{array}$ & $\begin{array}{l}-0.0849 \\
(0.86)\end{array}$ & $\begin{array}{l}-0.0182 \\
(0.25)\end{array}$ \\
\hline First class degree & $\begin{array}{l}0.0673 \\
(0.76)\end{array}$ & $\begin{array}{l}-0.0056 \\
(0.16)\end{array}$ & $\begin{array}{l}-0.0070 \\
(0.21)\end{array}$ & $\begin{array}{l}-0.0463 \\
(-0.62)\end{array}$ & $\begin{array}{l}-0.0082 \\
(-0.23)\end{array}$ \\
\hline $\begin{array}{l}\text { Upper second class } \\
\text { degree }\end{array}$ & $\begin{array}{l}0.0316 \\
(0.45)\end{array}$ & $\begin{array}{l}0.0294 \\
(1.03)\end{array}$ & $\begin{array}{l}0.0324 \\
(1.14)\end{array}$ & $\begin{array}{l}0.0723 \\
(1.52)\end{array}$ & $\begin{array}{l}-0.0024 \\
(0.07)\end{array}$ \\
\hline $\mathrm{PhD}$ & $\begin{array}{l}0.0913 \\
(1.20)\end{array}$ & $\begin{array}{l}0.1049 \\
(3.51)\end{array}$ & $\begin{array}{l}0.1062 \\
(3.54)\end{array}$ & $\begin{array}{l}0.1650 \\
(2.87)\end{array}$ & $\begin{array}{l}0.0740 \\
(2.25)\end{array}$ \\
\hline Academic staff & $\begin{array}{l}0.1851 \\
(2.56)\end{array}$ & $\begin{array}{l}0.0803 \\
(2.96)\end{array}$ & $\begin{array}{l}0.0789 \\
(2.90)\end{array}$ & & \\
\hline Medicine subject area & $\begin{array}{l}0.2104 \\
(2.87)\end{array}$ & $\begin{array}{l}0.1871 \\
(6.04)\end{array}$ & $\begin{array}{l}0.1847 \\
(5.96)\end{array}$ & $\begin{array}{l}0.1699 \\
(2.79)\end{array}$ & $\begin{array}{l}0.1953 \\
(5.89)\end{array}$ \\
\hline Temporary post & $\begin{array}{l}-0.1968 \\
(-2.93)\end{array}$ & $\begin{array}{l}-0.1733 \\
(5.79)\end{array}$ & $\begin{array}{l}-0.1711 \\
(5.71)\end{array}$ & $\begin{array}{l}-0.1184 \\
(2.42)\end{array}$ & $\begin{array}{l}-0.2383 \\
(6.37)\end{array}$ \\
\hline Full time post & $\begin{array}{l}0.0731 \\
(0.77)\end{array}$ & $\begin{array}{l}0.3545 \\
(8.90)\end{array}$ & $\begin{array}{l}0.3535 \\
(8.86)\end{array}$ & $\begin{array}{l}0.3472 \\
(5.51)\end{array}$ & $\begin{array}{l}0.3347 \\
(6.61)\end{array}$ \\
\hline Sample size & 93 & 613 & 613 & 276 & 337 \\
\hline Adjusted R squared & 0.60 & 0.54 & 0.54 & 0.49 & 0.58 \\
\hline
\end{tabular}




\section{References}

Akerlof, G. A. (1998). Men without children. The Economic Journal, 108, 287-309.

Antonovics, K., Town, R. (2004). Are all the good men married? Uncovering the sources of the marital wage premium. American Economic Review, Papers and Proceedings, 94, 317-321.

Bardasi, E., Taylor, M. (2005). Marriage and wages. Working Papers of the Institute for Social and Economic Research, University of Essex. Forthcoming, Economica. http://www.iser.essex.ac.uk/pubs/workpaps/pdf/2005-01.pdf

Becker, G. S. (1965). A Theory of the allocation of time. The Economic Journal, 75, 493517.

Black, D., Gates, G.,Sanders, S., Taylor, L. (2000). Demographics of the gay and lesbian population in the United States: evidence from systematic data sources. Demography, 37, 139-154.

Blandford, J.M. (2003). The nexus of sexual orientation and gender in the determination of earnings. Industrial and Labor Relations Review, 56, 622-642.

Booth, A.L. (1993). Private sector training and graduate earnings. The Review of Economics and Statistics, 75, 164-170.

Booth, A.L., Frank, J., (2006). What can gay men tell us about the male marriage premium. Unpublished manuscript.

Carpenter, C., Gates, G. (2004). Partnership-based selection among gay men and lesbians: implications for census research. Proceedings of the Social Statistics Section, American Statistical Association.

Chun, H., Lee, I. (2001). Why do married men earn more: productivity or marriage selection? Economic Inquiry, 39, 307-19.

Ehrenberg, R.G. (2003). Studying ourselves: the academic labor market. Journal of Labor Economics, 21, 267-88.

Frank, J. (2006). Gay glass ceilings. Economica, 73, 485-508.

Ginther, D., Zavodny, M. (2001). Is the male marriage premium due to selection? The effect of shotgun weddings on the return to marriage. Journal of Population Economics, 14, 313-28.

Jepsen, L.K., Jepsen, C.A. (2002). An empirical analysis of same-sex and opposite-sex couples. Demography, 39, 435-53.

Korenman, S ., Neumark, D. (1991). Does marriage really make men more productive? Journal of Human Resources, 26, 282-307. 
Loh, E.S. (1996). Productivity differences and the marriage wage premium for white males. Journal of Human Resources, 31, 566-89.

Lundberg, S., Rose, E. (2002). The Effects of sons and daughters on men's labor supply and wages. Review of Economics and Statistics, 84, 251-68.

Mamun, A. (2004). Is there a cohabitation premium in men's earnings? University of Washington Center for Research on Families Discussion Paper.

Stratton, L.S. (2002). Examining the wage differential for married and cohabiting men. Economic Inquiry, 40, 199-212. 